\title{
EKSPERIMENTASI PEMBELAJARAN MATEMATIKA DENGAN \\ PENDEKATAN CONTEXTUAL TEACHING AND LEARNING (CTL) \\ DITINJAU DARI KEMAMPUAN AWAL SISWA KELAS VII SMP \\ NEGERI KABUPATEN SUKOHARJO
}

\author{
Lukman Harun \\ IKIP PGRI Semarang \\ Luck_1909@yahoo.com
}

\begin{abstract}
ABSTRAK. Tujuan penelitian untuk mengetahui: (1) apakah pembelajaran CTL lebih baik daripada ekspositori, (2) apakah siswa memiliki kemampuan awal tinggi mempunyai prestasi belajar matematika lebih baik daripada sedang dan rendah, (3) apakah perbedaan pembelajaran CTL dan ekspositori tergantung kepada kemampuan awal.

Penelitian ini adalah penelitian eksperimen semu. Populasi penelitian adalah siswa kelas VII SMP Negeri Sukoharjo Tahun Pelajaran 2009/2010. Teknik analisis datanya menggunakan analisis variansi dua jalan $2 \times 3$ dengan sel tak sama dengan taraf signifikansi 5\%. Pengujian prasyarat analisis dilakukan dengan metode Lilliefors untuk uji normalitas dan metode Bartlett untuk uji homogenitas.

Dari hasil analisis disimpulkan: (1) CTL menghasilkan prestasi belajar matematika lebih baik dibandingkan ekspositori pada materi segi empat, (2) Prestasi belajar matematika siswa kemampuan awal tinggi lebih baik daripada siswa yang sedang dan rendah serta prestasi belajar matematika siswa kemampuan awal sedang lebih baik daripada siswa yang rendah pada materi segi empat, (3.a) Siswa kemampuan awal tinggi dan rendah mempunyai prestasi yang lebih baik pada pembelajaran dengan CTL (3.b) Pada pembelajaran dengan CTL maupun ekspositori, siswa kemampuan awal tinggi mempunyai prestasi belajar matematika lebih baik dibandingkan siswa sedang dan rendah, siswa dengan kemampuan awal sedang lebih baik dibandingkan siswa yang rendah.
\end{abstract}

Kata Kunci: Contextual Teaching and Learning, ekspositori dan kemampuan awal

ABSTRACT. The aims of research are to find out: (1) whether learning with CTL is better than the ekspositori in mathematics learning, (2) whether students with high initial ability is better than mathematics learning achievement of the students with medium and low initial ability, (3) whether difference learning between CTL and the ekspositori hang with initial ability and whether there was any learning achievement differences between students with high, medium and low initial ability in each learning method.

This research is a quasi experimental research. The population of this research is the students in grade VII Junior High School in Sukoharjo in academic year of 2009/2010. The technique of analyzing the data is using two ways variant analysis $2 \times 3$ with difference cell at the significance level of 5\%. The requirement test analysis is done by Lilliefors method for the normality test and the Bartlett method for the homogen test.

From the result of the analysis, it can be concluded that: (1) the CTL gives mathematics learning achievement better than the ekspositori in the material of quadrilateral, (2) mathematics learning achievement of the students with high initial ability better than 
medium and low initial ability in the material of quadrilateral, (3.a) the students with the high and low initial ability if due to CTL have a better learning achievement on mathematics than those due to expository, but the students with the medium initial ability have the same learning achievement on Mathematics due to CTL and expository, (3.b) In the CTL as well as expository, the students with high initial ability better than mathematics learning achievement of the students with medium and low initial ability.

Key words: Contextual Teaching and Learning, expository and initial ability

\section{PENDAHULUAN}

Perkembangan ilmu pengetahuan dan teknologi dari waktu ke waktu semakin pesat dan canggih, didukung pula oleh arus globalisasi yang semakin hebat. Fenomena tersebut memunculkan adanya persaingan dalam berbagai bidang kehidupan, diantaranya adalah bidang pendidikan.

Untuk mencapai keberhasilan pendidikan, guru dan siswa memegang peranan yang sangat penting dalam proses belajar mengajar. Di dalam mengajar pasti ada subjek yang belajar. Guru mempunyai tugas dan tanggung jawab yang luas. Selain sebagai pengajar, guru juga dituntut berlaku sebagai pembimbing dan pendidik.

Penggunaan pendekatan pembelajaran dalam menyajikan pelajaran sangat berpengaruh terhadap prestasi belajar siswa. Penggunaan pendekatan pembelajaran yang bervariasi akan mengatasi kejenuhan siswa dalam menerima pelajaran. Sehingga dapat dikatakan bahwa pendekatan pembelajaran dalam menyajikan materi pelajaran berpengaruh pada tingkat pemahaman siswa.

Salah satu pendekatan yang diharapkan dapat membuat siswa lebih bermakna adalah pendekatan Contextual Teaching and Learning (CTL). Pendekatan CTL mengaitkan materi yang dipelajari dengan situasi dunia nyata, sehinga siswa dapat membuat hubungan antara pengetahuan yang diperolehnya dengan penerapannya dalam kehidupan sehari-hari, anggota keluarga dan masyarakat.

Salah satu masalah dalam pengajaran matematika yaitu masih rendahnya pretasi belajar siswa. Rendahnya prestasi belajar siswa ini mungkin disebabkan kurang tepatnya pemilihan pendekatan pembelajaran yang digunakan guru dalam menyampaikan suatu pokok bahasan. Selain itu belum digunakannya fasilitas 
belajar dalam setiap kegiatan belajar mengajar kemungkinan dapat mempengaruhi prestasi belajar matematika siswa. Oleh karena itu, dengan penerapan CTL diharapkan siswa menemukan banyak hal yang menarik dalam mempelajari matematika, sehingga bisa meningkatkan prestasi belajar matematika.

Rendahnya hasil belajar matematika siswa juga sering dikaitkan dengan asal sekolah dasar yang sangat beragam. Artinya dapat diduga bahwa kemampuan awal siswa tinggi, kemampuan awal sedang dan kemampuan awal rendah dapat mempengaruhi hasil prestasi belajar matematika .

Pembelajaran matematika pada materi segi empat membutuhkan kemampuan siswa untuk mengaitkan dengan materi sebelumnya yaitu garis dan sudut. Dengan menggunakan pendekatan pembelajaran CTL, proses pembelajaran menjadi lebih bermakna karena siswa akan lebih aktif dalam memahami konsep dengan mengaitkan materi yang dipelajari dengan materi yang sudah dipelajari.

Kemampuan awal siswa memiliki peranan yang sangat penting dalam belajar matematika, karena terdapat keterkaitan antara materi yang satu dengan materi yang lainnya. Sehingga cepat lambatnya siswa dalam menguasai materi dipengaruhi oleh tingkat kemampuan awal. Siswa yang memiliki kemampuan awal tinggi dan sedang mungkin tidak mengalami kesulitan dalam memahami materi sehingga memiliki prestasi belajar matematika yang lebih baik. Tetapi bagi siswa yang memiliki kemampuan awal rendah mungkin mengalami banyak kesulitan dalam memahami materi sehingga mengakibatkan rendahnya prestasi belajar matematika siswa.

Berdasarkan latar belakang tersebut dapat dirumuskan masalah penelitian sebagai berikut:

a. Apakah peserta didik yang diberi pembelajaran matematika dengan menggunakan pendekatan CTL mempunyai prestasi belajar yang lebih baik daripada peserta didik yang diberi pembelajaran matematika dengan ekspositori?

b. Apakah peserta didik yang kemampuan awalnya tinggi lebih baik prestasi belajarnya daripada peserta didik yang kemampuan awalnya sedang atau rendah, dan peserta didik yang kemampuan awalnya sedang lebih baik 
prestasi belajarnya daripada peserta didik yang kemampuan awalnya rendah?

c. Apakah perbedaan pembelajaran dengan pendekatan pembelajaran CTL dan ekspositori tergantung pada kemampuan awal siswa dan apakah siswa dengan kemampuan awal tinggi mempunyai prestasi yang lebih baik dibandingkan siswa dengan kemampuan awal sedang maupun rendah dan siswa dengan kemampuan awal sedang mempunyai prestasi yang lebih baik dibanding siswa dengan kemampuan awal rendah pada masing-masing pendekatan pembelajaran (CTL dan ekspositori)?

Tujuan yang akan dicapai dari penelitian ini adalah sebagai berikut:

a. Untuk mengetahui peserta didik yang diberi pembelajaran matematika dengan menggunakan pendekatan CTL mempunyai prestasi belajar yang lebih baik daripada peserta didik yang diberi pembelajaran matematika dengan ekspositori.

b. Untuk mengetahui peserta didik yang kemampuan awalnya tinggi lebih baik prestasi belajarnya daripada peserta didik yang kemampuan awalnya sedang atau rendah, dan peserta didik yang kemampuan awalnya sedang lebih baik prestasi belajarnya daripada peserta didik yang kemampuan awalnya rendah.

c. Untuk mengetahui apakah pada masing-masing tingkat kemampuan awal tinggi, sedang dan rendah, pendekatan pembelajaran CTL akan menghasilkan prestasi belajar matematika siswa yang lebih tinggi dibandingkan dengan pendekatan ekspositori dan mengetahui apakah pada masing-masing pendekatan tersebut tingkat kemampuan awal siswa akan berpengaruh pada prestasi belajar siswa.

Dengan penelitian ini peneliti berharap semoga hasilnya dapat berguna untuk:

a. Memberi masukan kepada guru atau calon guru matematika dalam menentukan metode mengajar yang tepat, yang dapat menjadi alternatif lain selain metode yang biasa digunakan guru (metode konvensional) dalam pelajaran matematika. 
b. Memberikan informasi kepada guru atau calon guru untuk lebih menekankan siswa pada kebermaknaan proses belajar mengajar.

c. Bahan pertimbangan dan masukan atau referensi ilmiah dan menumbuhkan motivasi untuk meneliti pada mata pelajaran lain atau permasalahan yang prosedur penelitiannya hampir sama.

\section{METODE PENELITIAN}

Penelitian ini merupakan penelitian eksperimen semu. Karena pada pelaksanaan penelitian ini peneliti tidak mungkin mengontrol semua variabel. Budiyono (2003: 82) mengemukakan bahwa "Tujuan penelitian eksperimen semu adalah untuk memperoleh informasi yang merupakan perkiraan bagi informasi yang dapat diperoleh dengan eksperimen yang sebenarnya dalam keadaan yang tidak memungkinkan untuk mengontrol dan atau memanipulasi semua variabel yang relevan".

Menurut Suharsimi Arikunto (2003: 115) "Populasi adalah keseluruhan subyek penelitian". Populasi dalam penelitian ini adalah siswa SMP Negeri Kabupaten Sukoharjo kelas VII semester genap tahun pelajaran 2009/2010 yang berjumlah 41 SMP Negeri.

Menurut Suharsimi Arikunto (2003: 115) "Sampel adalah sebagai atau wakil dari populasi yang akan diteliti”. Dalam penelitian, tidak perlu untuk meneliti semua subyek dalam populasi, karena selain membutuhkan biaya yang besar juga memerlukan waktu yang lama. Untuk itu dengan mengambil sebagian subyek suatu populasi atau sering disebut dengan teknik pengambilan sampel diharapkan hasil penelitian yang diperoleh dapat menggambarkan populasi yang bersangkutan.

Teknik pengambilan sampel dalam penelitian ini adalah Stratified Cluster Random Sampling, dimana populasi siswa SMP Negeri Kabupaten Sukoharjo terdiri dari 41 SMP Negeri yang terbagi dalam 3 kelompok berdasarkan peringkat sekolah, yaitu tinggi, sedang dan rendah. Kemudian secara acak dipilih 1 sekolah yang mewakili masing-masing kelompok dan diperoleh SMP Negeri 1 Gatak dari kelompok tinggi, SMP Negeri 1 Baki dari kelompok sedang dan SMP Negeri 2 
Baki dari kelompok rendah. Setelah terpilih 1 sekolah untuk setiap kelompok kemudian dipilih 2 kelas yang akan dipergunakan sebagai kelompok eksperimen dan kelompok kontrol dengan teknik Random Sampling. Sehingga diperoleh sampel yang tediri 2 kelompok yang terdiri dari 6 kelas, yaitu 3 kelas sebagai kelompok eksperimen dan 3 kelas sebagai kelompok kontrol.

Dalam penelitian ini terdapat dua variabel bebas, yaitu pendekatan pembelajaran dan kemampuan awal siswa pada mata pelajaran matematika serta satu variabel terikat yaitu prestasi belajar matematika siswa. Variabel terikat dalam penelitian ini adalah prestasi belajar matematika siswa.

Metode yang digunakan untuk mengumpulkan data dalam penelitian ini ada dua cara, yaitu metode dokumentasi dan metode tes.

Uji keseimbangan digunakan untuk mengetahui apakah terdapat perbedaan kemampuan matematika antara kelas dengan pendekatan pembelajaran CTL dengan kelas dengan pendekatan pembelajaran ekspositori, uji keseimbangan ini dilakukan sebelum eksperimen dilaksanakan. Uji keseimbangan dengan menggunakan data nilai ulangan umum siswa kelas VII mata pelajaran matematika pada semester gasal. Uji keseimbangan dilakukan dengan metode uji beda mean $t$.

Teknik analisis data yang digunakan dalam penelitian ini adalah analisis variansi dua jalan sel tak sama. Sebelum melakukan analisis akan dilakukan uji prasyarat yaitu uji normalitas dan uji homogenitas. Tujuan melaksanakan analisis variansi dua jalan ini adalah untuk menguji perbedaan efek baris, kolom dan kombinasi efek baris dan kolom terhadap variabel terikat. Analisis variansi dua jalan yang digunakan adalah analisis variansi dengan sel tak sama.

Jika hasil analisis variansi menunjukkan hipotesis nolnya ditolak, maka dilakukan uji komparasi ganda dengan menggunakan uji Scheffe' karena metode tersebut akan menghasilkan beda rerata dengan tingkat signifikansi yang kecil. Tujuan dari komparasi ganda adalah untuk mengetahui perbedaan rerata. Adapun prosedur uji komparasi ganda dengan metode Sceffe' yaitu:

a. Mengidentifikasi semua pasangan komparasi rerata.

b. Merumuskan hipotesis yang bersesuaian dengan komparasi tersebut. 
c. Mencari harga statistik uji F.

d. Menentukan keputusan uji (beda rataan) untuk setiap pasang komparasi rataan $\mathrm{H}_{0}$ ditolak jika $F_{\text {hit }} \in D K$.

e. Menentukan kesimpulan dari uji yang sudah ada.

\section{HASIL DAN PEMBAHASAN}

Hasil perhitungan uji keseimbangan yang menggunakan uji t diperoleh nilai $t_{\text {hit }}=0,7084$ dan $\alpha=0,05$ yang berarti pada taraf signigikansi 5\% hipotesis nol diterima. Sehingga dapat disimpulkan bahwa antara kelas dengan pendekatan pembelajaran CTL dan kelas dengan pendekatan pembelajaran ekspositori memiliki kemampuan awal yang sama atau dengan kata lain ditinjau dari kemampuan awal kedua kelas dalam keadaan seimbang.

Hasil perhitungan anava dua jalan sel tak sama disajikan pada tabel berikut.

Tabel 1.Rangkuman Analisis Variansi Dua Jalan Sel Tak Sama

\begin{tabular}{|l|c|c|c|c|c|}
\hline \multicolumn{1}{|c|}{ Sumber } & JK & dk & RK & F $_{\text {hit }}$ & $\mathbf{F}_{\text {tabel }}$ \\
\hline $\begin{array}{l}\text { Pendekatan } \\
\text { Pembelajaran (A) }\end{array}$ & 2060,63 & 1 & 2060,63 & 30,8048 & 3,84 \\
\hline Kemampuan awal (B) & 17786,2 & 2 & 8893,11 & 132,945 & 3 \\
\hline Interaksi (AB) & 436,474 & 2 & 218,237 & 3,26247 & 3 \\
\hline Galat (G) & 14917,2 & 223 & 66,8933 & - & - \\
\hline Total & 35200,5 & 228 & - & - & - \\
\hline
\end{tabular}

Berdasarkan tabel di atas dapat dilihat bahwa $\mathrm{H}_{0 \mathrm{~A}}$ ditolak, $\mathrm{H}_{0 \mathrm{~B}}$ ditolak dan $\mathrm{H}_{0 \mathrm{AB}}$ ditolak. Dapat disimpulkan bahwa:

a) Terdapat perbedaan efek antara pendekatan pembelajaran matematika terhadap prestasi belajar matematika.

b) Terdapat perbedaan efek antara kemampuan awal siswa terhadap prestasi belajar matematika.

c) Terdapat efek interaksi antara pendekatan pembelajaran dengan kemampuan awal terhadap prestasi belajar matematika. 


\section{Uji Komparansi Ganda}

Berdasarkan rataan marginal dapat disimpulkan bahwa pendekatan pembelajaran CTL menghasilkan prestasi belajar matematika lebih baik dibandingkan pendekatan pembelajaran ekspositori.

Dari uji komparasi ganda antar kolom di atas diperoleh bahwa terdapat perbedaan pengaruh antara kemampuan awal tinggi dan sedang terhadap prestasi belajar matematika siswa, terdapat perbedaan pengaruh antara kemampuan awal tinggi dan rendah terhadap prestasi belajar matematika siswa dan terdapat perbedaan pengaruh antara kemampuan awal sedang dan rendah terhadap prestasi belajar matematika siswa.

\section{Pembahasan}

Dari hasil analisis variansi diperoleh $\mathrm{F}_{\mathrm{a}}=30,8048>3,84=\mathrm{F}_{0,05 ; 1 ; 222}$. Nilai $\mathrm{F}_{\mathrm{a}}$ terletak di daerah kritik maka $\mathrm{H}_{\mathrm{oA}}$ ditolak berarti pendekatan pembelajaran berpengaruh terhadap prestasi belajar pada materi segi empat. Dari rataan marginalnya $\left(\overline{X_{1}}=68.9652>64.3772=\overline{X_{2}}\right.$ ) menunjukkan bahwa pembelajaran dengan pendekatan pembelajaran CTL menghasilkan prestasi belajar matematika yang lebih baik dibandingkan pendekatan pembelajaran ekspositori pada materi segi empat.

Berdasarkan hasil analisis variansi diperoleh $\mathrm{F}_{\mathrm{b}}=132,945$ lebih besar dari $\mathrm{F}_{\text {tabel }}=$ 3,00 maka $\mathrm{H}_{0 \mathrm{~B}}$ ditolak. Sehingga diperoleh kesimpulan bahwa terdapat perbedaan prestasi belajar siswa dengan kemampauan awal tinggi, sedang, dan rendah pada pokok bahasan segi empat.

Berdasarkan hasil analisis variansi diperoleh $\mathrm{F}_{\mathrm{ab}}=3,26247$ lebih besar dari $\mathrm{F}_{\text {tabel }}=$ 3,00 maka $\mathrm{H}_{0 \mathrm{AB}}$ ditolak. Hal ini berarti terdapat interaksi antara penggunaan pendekatan pembelajaran dengan kategori kemampuan awal terhadap prestasi belajar matematika pada pokok bahasan segi empat. 


\section{KESIMPULAN DAN SARAN}

\subsection{Kesimpulan}

Berdasarkan kajian teori dan analisis yang mengacu pada perumusan masalah yang telah diuraikan, maka dapat disimpulkan bahwa:

1. Pendekatan pembelajaran Contextual Teaching and Learning (CTL) menghasilkan prestasi belajar matematika lebih baik dibandingkan pendekatan pembelajaran ekspositori pada materi segi empat.

2. Prestasi belajar matematika siswa yang memiliki kemampuan awal tinggi lebih baik daripada prestasi belajar matematika siswa yang memiliki kemampuan awal sedang dan rendah serta prestasi belajar matematika siswa yang memiliki kemampuan awal sedang lebih baik daripada prestasi belajar matematika siswa yang memiliki kemampuan awal rendah pada materi segi empat.

3. a. Perbedaan pendekatan pembelajaran tergantung pada kemampuan awal siswa. Hal ini dapat diuraikan sebagai berikut:

1) Pada siswa dengan kemampuan awal tinggi, prestasi belajar siswa yang diberi pembelajaran dengan pendekatan pembelajaran CTL lebih baik daripada prestasi belajar siswa yang diberi pembelajaran dengan pendekatan ekspositori.

2) Pada siswa dengan kemampuan awal sedang, tidak terdapat perbedaan antara prestasi belajar siswa yang diberi pembelajaran dengan pendekatan CTL maupun dengan siswa yang diberi pembelajaran dengan pendekatan ekspositori.

3) Pada siswa dengan kemampuan awal rendah, prestasi belajar siswa yang diberi pembelajaran dengan pendekatan pembelajaran CTL lebih baik daripada prestasi belajar siswa yang diberi pembelajaran dengan pendekatan ekspositori.

b. Pada pembelajaran dengan pendekatan CTL maupun ekspositori, siswa dengan kemampuan awal tinggi mempunyai prestasi belajar matematika lebih baik dibandingkan siswa dengan kemampuan awal sedang dan rendah, siswa dengan kemampuan awal sedang mempunyai prestasi 
belajar matematika lebih baik dibandingkan siswa dengan kemampuan awal rendah.

\subsection{Saran}

Ada beberapa hal yang perlu peneliti sarankan, yaitu:

1. Bagi Kepala Sekolah

Seorang Kepala Sekolah perlu mendorong guru agar senantiasa kreatif dan inovatif dalam pembelajaran. Dalam hal ini Kepala Sekolah perlu memberikan apresiasi dan dukungan dalam pelaksanaan pembelajaran yang sesuai dengan materi dan kondisi siswa dan menyediakan fasilitas-fasilitas yang dibutuhkan supaya pembelajaran yang kreatif dan inovatif bisa dilaksanakan.

2. Bagi para guru

a. Seorang guru matematika diharapkan dapat melakukan kegiatan pembelajaran secara baik dengan menyediakan waktu yang cukup dalam mempersiapkan pembelajaran sehingga bisa mengkaitkan materi pelajaran dengan kehidupan sehari-hari dalam pembelajaran sehingga materi lebih mudah diterima siswa.

b. Seorang guru hendaknya mengenal kondisi siswa sehingga bisa memotivasi dan memberikan dukungan yang tepat kepada setiap siswa. Seorang guru hendaknya mengenal tingkat kemampuan siswanya sehingga bisa memberikan dukungan yang optimal sesuai dengan kondisi siswa.

3. Bagi para peneliti/ calon peneliti

Diharapkan dapat mengembangkan hasil penelitian ini dalam lingkup yang lebih luas. Penulis berharap, para peneliti/ calon peneliti dapat meneruskan atau mengembangkan penelitian ini untuk variabel-variabel lain yang sejenis atau pendekatan pembelajaran lain yang lebih inovatif, sehingga dapat menambah wawasan dan dapat lebih meningkatkan kualitas pembelajaran khususnya dan pendidikan pada umumnya.

\section{DAFTAR PUSTAKA}

Budiyono. (2003). Metodologi Penelitian Pendidikan. Surakarta: UNS Press. Suharsimi Arikunto. (2003). Prosedur Penelitian. Jakarta: CV. Rineka Cipta. 